\title{
Efek Imunomodulator Ekstrak Etanol Herba Krokot (Portulaca oleracea L.) terhadap Tikus Putih (Rattus norvegicus) Jantan dengan Parameter Delayed Type Hypersensitivity (DTH)
}

\section{(Effect of Immunomodulator of Purslane Herb Ethanol (Portulaca oleracea L.) on Rat (Rattus norvegicus) with Delayed Type Hypersensitivity (DTH) Parameter)}

\author{
Bayu Putra $^{*}$, Rizqi Nur Azizah ${ }^{1}$, Eka Maryam Nopriyanti ${ }^{1}$ \\ ${ }^{1 *}$ Fakultas Farmasi, Universitas Muslim Indonesia, Makassar, Indonesia. \\ E-mail: $\underline{\text { bayu.putra@umi.ac.id }}$
}

Article Info:

Received: 01 November 2019

in revised form: 01 November 2019

Accepted: 14 Desember 2019

Available Online: 02 Maret 2020

Keywords:

Portulaca oleracea $\mathrm{L}$. Immunomodulators

Delayed Type Hypersensitivity (DTH)

Corresponding Author: Bayu Putra

Jurusan Farmasi

Fakultas Farmasi

Universitas Muslim Indonesia

Makassar

90231

Indonesia

email: bayu.putra@umi.ac.id

\begin{abstract}
Portulaca oleracea $\mathrm{L}$. is one of the plants empirically used as medicine and contains flavonoid compounds assumed to have an immunomodulatory effect. The research aimed to determine the immunomodulatory effect of ethanol extract of Portulaca oleracea L by Delayed Type Hypersensitivity parameter. The research used 20 male rats (Rattus norvegicus) divided into 5 groups where each group consisted of 4 . Group I as a normal group (without treatment), group II (NaCMC control), group III, IV and V (treatment groups) were given EEHK with doses of $100 \mathrm{mg} / \mathrm{kg} \mathrm{BW}, 200 \mathrm{mg} / \mathrm{kg} \mathrm{BW}$, and $400 \mathrm{mg} / \mathrm{kg}$ BW doses. The dosage form was orally given for 7 days. On day 3, the rats were induced with SDMD antigen $10 \% \mathrm{v} / \mathrm{v}$ by intraperitonial and intraplantar on day 7 . The observations were conducted by measuring the volume change of the rat's feet at the 4th, 24th, and 48th hours using a pletismometer. The research data obtained were statistically processed using Paired Samples T Test, One-Way Anova and Post Hoc LSD tests. The results of the research showed that the ethanol extract of common purslane was effective as an immunomodulator.
\end{abstract}

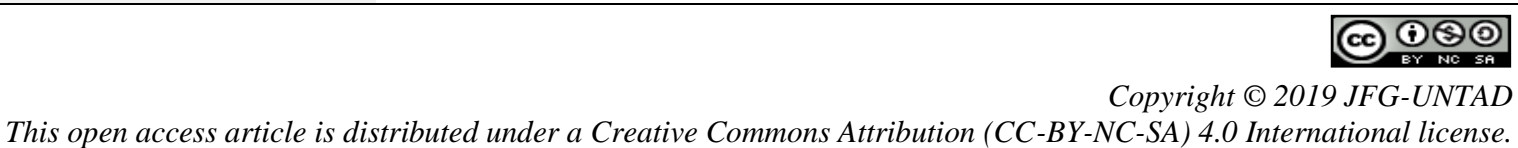

How to cite (APA $6^{\text {th }}$ Style):

Putra, B., Azizah, R. N., Nopriyanti, E. M. (2020). Efek Imunomodulator Ekstrak Etanol Herba Krokot (Portulaca oleracea L.) terhadap Tikus Putih (Rattus norvegicus) Jantan dengan Parameter Delayed Type Hypersensitivity (DTH). Jurnal Farmasi Galenika :Galenika Journal of Pharmacy (e-Journal), 6(1), 20-25. doi:10.22487/j24428744.2020.v6.i1.14106 


\section{ABSTRAK}

Herba krokot (Portulaca oleracea L.) merupakan salah satu tanaman yang secara empiris digunakan sebagai obat serta mengandung senyawa flavonoid yang diduga dapat memberikan efek sebagai imunomodulator. Penelitian ini bertujuan untuk membuktikan efek imunomodulator ekstrak etanol herba krokot (Portulaca oleracea L.) dengan parameter Delayed Type Hypersensitivity. Penelitian ini menggunakan 20 ekor tikus (Rattus norvegicus) jantan yang dibagi menjadi 5 kelompok. Setiap kelompok terdiri dari 4 ekor tikus. Kelompok I sebagai kelompok normal (tanpa perlakuan), kelompok II (kontrol NaCMC), kelompok III, IV dan V (kelompok perlakuan) yang diberi EEHK dengan dosis masing-masing $100 \mathrm{mg} / \mathrm{kgBB}, 200 \mathrm{mg} / \mathrm{kgBB}$, dan $400 \mathrm{mg} / \mathrm{kgBB}$. Pemberian sediaan uji diberikan secara oral selama 7 hari. Pada hari ke-3 hewan uji diinduksi dengan antigen SDMD $10 \% \mathrm{v} / \mathrm{v}$ secara intraperitonial dan intraplantar pada hari ke-7. Pengamatan dilakukan dengan mengukur perubahan volume kaki tikus pada jam ke-4, ke-24 dan ke-48 menggunakan pletismometer. Data penelitian yang diperoleh diolah secara statistik menggunakan uji Paired Samples T Test, One-Way Anova dan Post Hoc LSD. Berdasarkan hasil penelitian dapat ditarik kesimpulan bahwa Ekstrak Etanol Herba Krokot (Portulaca oleracea L.) efektif sebagai imunomodulator.

Kata kunci: Herba Krokot (Portulaca oleracea L.), Imunomodulator, Delayed Type Hypersensitivity (DTH).

\section{PENDAHULUAN}

Respon imun tubuh tergantung pada kemampuan komponen sistem imun dalam mengenali zat asing serta membangkitkan dan melakukan reaksi yang tepat dalam mengeliminasi zat asing tersebut (Antari, 2017).

Sistem kekebalan tubuh manusia terbagi menjadi dua yaitu sistem kekebalan tubuh spesifik dan nonspesifik yang berfungsi melindungi tubuh dari paparan zat asing yang dapat menimbulkan suatu penyakit bagi tubuh. Sistem kekebalan tubuh non-spesifik dapat mendeteksi adanya benda asing sehingga melindungi tubuh dari kerusakan yang diakibatkan, tetapi tidak dapat mengenali benda asing tersebut, seperti kulit, kelenjar keringat, air mata, rambut pada lubang hidung. Sedangkan sistem kekebalan tubuh spesifik dapat menghancurkan zat asing yang berhasil melewati sistem kekebalan tubuh non-spesifik, meliputi imunitas humoral (limfosit B) dan imunitas seluler (limfosit T) (Sri Harti, 2013).

Apabila keadaan dimana fungsi dan jumlah sel imun kurang memadai, salah satu upaya untuk meningkatkannya adalah dengan pemberian imunomodulator menjadi sangat efektif (Kusmardi \& Enif, 2007). Imunomodulator adalah zat yang dapat memodulasi (mengubah atau mempengaruhi) sistem imun tubuh menjadi ke arah normal (Praworo, 2011). Beberapa senyawa alam memiliki kemampuan dapat meningkatkan aktivitas sistem imun yaitu golongan flavanoid, kurkumin, limonoid, vitamin C, vitamin E dan katekin (Devagaran \& Diantini, 2012).

Tanaman herba krokot (Portulaca olerace L.) merupakan salah satu dari tanaman yang digunakan sebagai pengobatan. Herba krokot telah banyak digunakan oleh masyarakat sebagai obat tradisional diantaranya obat penurun panas, antiseptik, vermifuge. Disamping itu beberapa penelitian menunjukkan berbagai efek farmakologi, termasuk antibakteri, antiulcerogenik, anti-inflamasi, antioksidan, dan penyembuhan luka (Zhou et al., 2015). Pada penilitian Devagaran \& Diantini (2012) menunjukkan bahwa antara senyawa yang memiliki kemampuan dapat meningkatkan aktivitas sistem imun adalah golongan flavonoid, kurkumin, limonoid, vitamin C, vitamin E dan katekin. Menurut Zhou et al., (2015) berbagai macam senyawa telah diisolasi dari tanaman krokot (Portulaca oleracea L.) seperti flavonoid, alkaloid, polisakarida, asam lemak, terpenoid, sterol, protein, vitamin dan mineral. Tanaman krokot juga menyediakan sumber manfaat nutrisi karena kaya asam lemak omega-3 dan sifat antioksidan. 
Hasil penelitian uji efek antiinflamasi yang dilakukan Andayani et al., (2018) menunjukkan bahwa ekstrak etanol herba krokot memiliki efek antiinflamasi pada udem kaki tikus jantan dengan besar daya antiinflamasi dimana dosis efektif adalah $400 \mathrm{mg}$ yaitu 30,20\%.

\section{METODE PENELITIAN}

\section{Alat dan Bahan}

Alat-alat yang digunakan adalah batang pengaduk, cawan porselin, gelas arloji, gelas kimia (pyrex), gelas ukur (pyrex), kanula, mikropipet (uawei), pletismometer (panlab), sendok tanduk, sentrifuge, seperangkat alat maserasi, timbangan analitik (ohaus), dan timbangan hewan (ohaus), dan vial. Bahan-bahan yang digunakan adalah air suling, aluminium foil, ekstrak herba krokot (Portulaca oleracea L.), etanol 96\%, larutan PBS (Phospat Buffered Saline) pH 7,2, sel darah merah domba (SDMD) $10 \% \mathrm{v} / \mathrm{v}, \mathrm{NaCl} 0,9 \%$, Na CMC $1 \% \mathrm{~b} / \mathrm{v}$, spoit $1 \mathrm{~mL}$ dan $3 \mathrm{~mL}$ (disposable syringe), dan tabung eppendorf.

\section{Metode}

\section{Pembuatan ekstrak Herba krokot (Portulaca oleracea L.)}

Serbuk simplisia herba krokot (Portulaca oleracea L.) ditimbang sebanyak 500 gram dan dimasukkan ke dalam wadah. Serbuk direndam dengan pelarut etanol $96 \%$ selama 1 x 24 jam pada suhu kamar. Pengadukan dilakukan sesekali selama 6 jam kemudian didiamkan selama 18 jam. Setelah proses maserasi selesai kemudian dilakukan penyaringan sehingga didapatkan filtrat dan residu, residu yang didapat dimaserasi kembali dengan pelarut yang baru dan didiamkan kembali selama 24 jam. Hasil filtrat dari maserasi pertama dicampur dengan hasil filtrat maserasi kedua kemudian diuapkan dengan menggunakan Rotary Evaporator hingga diperoleh ekstrak kental.

\section{Pembuatan Na-CMC 1\% b/v}

Suspensi Na-CMC 1\% dibuat dengan cara ditimbang Na-CMC sebanyak 1 gram kemudian dimasukkan ke dalam gelas kimia $100 \mathrm{~mL}$. Dilarutkan dengan $10 \mathrm{~mL}$ aquades yang telah di didihkan sambil diaduk menggunakan batang pengaduk. Kemudian dicukupkan dengan aquades hingga 100 mL. (Wati et al, 2013)

\section{Pembuatan suspensi ekstrak Herba krokot (Portulaca oleracea L.)}

Ekstrak etanol herba krokot (Portulaca oleracea L.) yang diperoleh dari hasil ekstraksi dibuat dalam tiga variasi dosis yakni $100 \mathrm{mg} / \mathrm{kgBB}, 200 \mathrm{mg} / \mathrm{kgBB}$, dan $400 \mathrm{mg} / \mathrm{kgBB}$, kemudian masing-masing ekstrak ditimbang sebanyak 100mg, 200mg dan 400mg dan disuspensikan dengan $10 \mathrm{~mL} \mathrm{Na} \mathrm{CMC}$ $1 \% \mathrm{~b} / \mathrm{v}$.

\section{Pembuatan Suspensi Sel Darah Merah Domba (SDMD) 10\% v/v}

Sel darah merah domba (SDMD) ditampung dalam wadah yang bersih dan kering yang berisi EDTA sebagai antikoagulan. Pisahkan sel darah merah domba dan plasmanya dengan disentrifus pada kecepatan $1500 \mathrm{rpm}$. Lapisan atas yang berupa plasma dibuang dan pada lapisan bawah yang berupa sel darah merah ditambahkan PBS (Phosphat Buffered Saline) pH 7,2 sebanyak tiga kali volume SDMD yang tersisa dan dibolak-balik beberapa kali lalu disentrifus kembali. Pencucian dilakukan paling sedikit 3 kali sampai lapisan atas benar-benar jernih dan tidak berwarna. Setelah selesai, PBS dipisahkan dan diperoleh SDMD 100\%, kemudian ditambahkan PBS dengan jumlah yang sama hingga diperoleh suspensi SDMD 50\%. Untuk mendapatkan suspensi SDMD 10\%, selanjutnya dipipet 2 mL suspensi SDMD 50\% dan ditambahkan PBS 8 mL (Effendi dan Widiastuti, 2014; Emelda et al., 2015). 


\section{Perlakuan Hewan Uji}

Sebanyak 20 ekor tikus putih (Rattus norvegicus) jantan dibagi dalam 5 kelompok. Masing-masing kelompok terdiri dari 4 ekor tikus jantan. Kelompok I sebagai kontrol normal (tanpa perlakuan), kelompok II sebagai kontrol Na CMC 1\%, kelompok III diberikan sediaan uji ekstrak etanol herba krokot dengan dosis $100 \mathrm{mg} / \mathrm{kgBB}$, kelompok IV diberikan sediaan uji ekstrak etanol herba krokot dengan dosis $200 \mathrm{mg} / \mathrm{kgBB}$, kelompok $\mathrm{V}$ diberikan sediaan uji ekstrak etanol herba krokot dengan dosis $400 \mathrm{mg} / \mathrm{kgBB}$. Selama tujuh hari semua hewan uji diberi perlakuan sediaan ekstrak uji kecuali kelompok I (kontrol normal) dan II (kontrol NaCMC) secara peroral sesuai dengan volume pemberiannya. Pada hari ketiga kelompok II, III, IV dan V diinduksikan antigen SDMD 10\% v/v sebanyak $1 \mathrm{~mL}$ secara intraperitonial dan dihari ketujuh kelompok II, III, IV dan V diinduksikan kembali dengan antigen SDMD $10 \% \mathrm{v} / \mathrm{v}$ sebanyak $0,1 \mathrm{~mL}$ secara intraplantar. Pengukuran volume kaki hewan uji dilakukan pada hari ketujuh sebelum dan setelah penginduksian antigen SDMD $10 \%$ v/v secara intraplantar pada jam ke-4, -24, dan -48 menggunakan pletismometer (Faradilla, 2013).

\section{Analisis Data}

Data hasil pengukuran perubahan volume kaki tikus dianalisis secara statistik menggunakan uji statistik Paired Samples T test dan uji statistik One-Way Anova yang dilanjutkan dengan uji lanjutan Post Hoc LSD.

\section{HASIL DAN PEMBAHASAN}

Data hasil penelitian uji efek imunomodulator ekstrak etanol herba krokot (Portulaca oleracea L.) dengan menggunakan parameter Delayed Type Hypersensitivity (DTH) dapat dilihat pada tabel dibawah ini.

Tabel 1. Hasil pengukuran rata-rata perubahan volume kaki tikus setelah pemberian antigen sel darah merah domba (SDMD) $10 \% \mathrm{v} / \mathrm{v}$.

\begin{tabular}{ccccc}
\hline \multirow{2}{*}{ Kelompok } & \multicolumn{4}{c}{ Rata-rata volume kaki tikus \pm SD pada waktu (jam) } \\
\cline { 2 - 5 } & T0 & T4 & T24 & T48 \\
\hline I (Normal) & $0,33 \pm 0,03$ & $0,30 \pm 0,05$ & $0,32 \pm 0,04$ & $0,31 \pm 0,009$ \\
II (NaCMC 1\% b/v) & $0,30 \pm 0,03$ & $0,57 \pm 0,04$ & $0,51 \pm 0,04$ & $0,46 \pm 0,02$ \\
III (EEHK 100 & $0,31 \pm 0,02$ & $0,62 \pm 0,12$ & $0,38 \pm 0,02$ & $0,35 \pm 0,02$ \\
mg/kgBB) & $0,32 \pm 0,02$ & $0,48 \pm 0,05$ & $0,40 \pm 0,02$ & $0,34 \pm 0,01$ \\
IV (EEHK 200 & $0,34 \pm 0,02$ & $0,54 \pm 0,005$ & $0,43 \pm 0,01$ & $0,37 \pm 0,02$ \\
mg/kgBB) & & & & \\
V (EEHK 400 & & &
\end{tabular}

Keterangan :

EEHK : Ekstrak Eanol Herba Krokot

SDMD : Sel Darah Merah Domba

T0 : Pengukuran volume kaki awal hewan coba

T4 : Pengukuran pada jam ke-4 setelah induksi antigen

T24 : Pengukuran pada jam ke-24 setelah induksi antigen

T48 : Pengukuran pada jam ke-48 setelah induksi antigen

Sistem imun merupakan suatu sistem pertahanan tubuh yang berfungsi melindungi, mempertahankan dan menghancurkan antigen seperti bakteri, virus dan mikroorganisme lain yang dapat menyebabkan berbagai penyakit. Salah satu upaya untuk mempertahankan sistem imun adalah dengan pemberian 
imunomodulator. Imunomodulator adalah zat yang dapat memodulasi sistem imun sehingga dapat bekerja lebih baik.

Penelitian ini dilakukan dengan tujuan untuk menentukan efek imunomodulator dan dosis efektif dari ekstrak etanol herba krokot (Portulaca oleracea L.) dengan parameter Delayed Type Hypersensitivity (DTH) terhadap tikus putih (Rattus norvegicus) jantan yang diinduksi dengan sel darah merah domba (SDMD).

Hasil pengukuran berdasarkan tabel diatas menunjukkan bahwa semua kelompok perlakuan mengalami perubahan sebelum dan sesudah diinduksi dengan antigen. Induksi ditandai dengan adanya proses inflamasi pada kaki hewan coba. Pada kelompok normal, tidak terjadi perubahan volume kaki tikus, dikarenakan tidak adanya perlakuan terhadap kelompok tersebut dari T0 hingga T48 sehingga volume kaki dari kelompok tersebut tetap. Pada kelompok NaCMC dan kelompok ekstrak uji dengan dosis $100 \mathrm{mg} / \mathrm{kgBB}, 200 \mathrm{mg} / \mathrm{kgBB}$, dan $400 \mathrm{mg} / \mathrm{kgBB}$ mengalami peningkatan pembengkakan volume kaki pada T4 setelah penginduksian antigen sel darah merah domba (SDMD), dikarenakan antigen yang mengandung lipopolisakarida merangsang makrofag untuk melepaskan TNF (Tumor Necrosis Factor) dan IL-1 yang merupakan mediator inflamasi. Pada T24 terjadi pembengkakan yang disebabkan oleh aktivasi sel T yang dapat merangsang pelepasan sitokin (IL-12) dalam memproduksi IFN-y dengan meningkatkan fungsi sitolitik dari sel NK dan sel T sehingga merangsang tersekresinya IFN-y yang akan mengaktivasi makrofag untuk mengeliminasi antigen. Pembengkakan yang terjadi pada T24 disebabkan oleh peningkatan aktivasi dari makrofag dalam memproduksi sitokin sehingga terjadi penumpukan sitokin (IL-12) ditempat penginduksian. Hal ini menunjukkan reaksi hipersensitivitas tipe lambat yang berlangsung lambat. Berdasarkan teori hipersensitivitas tipe lambat (tipe IV), peningkatan volume kaki tidak terjadi selama 6-12 jam dan mencapai intensitas maksimal sesudah 24-72 jam (Bellanti, 1989). Pada T48 terjadi penurunan volume kaki tikus (Rattus norvegicus) pada semua kelompok uji kecuali pada kontrol NaCMC. Hal ini menunjukkan bahwa pemberian ekstrak dapat mempercepat terjadinya respon imun sehingga proses penurunan pembengkakan lebih cepat terjadi.

Dari hasil penelitian dan analisis data menunjukkan bahwa ekstrak etanol herba krokot memiliki kemampuan sebagai imunomodulator. Berdasarkan volume kaki pada T24 menunjukkan bahwa kelompok uji ekstrak dosis $400 \mathrm{mg} / \mathrm{kgBB}$ mengalami pembengkakan paling besar diantara kelompok uji ekstrak yang lain, sehingga dianggap bahwa dosis tersebut yang efektif sebagai imunomodulator.

Pada penelitian ini diketahui bahwa ekstrak etanol herba krokot (Portulaca oleracea L.) dapat berefek sebagai imunomodulator. Hal tersebut didasarkan pada penelitian yang telah dilakukan oleh Park et al., (2019) bahwa Portulaca oleracea L. berbasis ekstrak kompleks dapat digunakan sebagai agen imunostimulan dalam obat-obatan maupun makanan. Hal ini diduga karena adanya kandungan senyawa flavonoid berdasarkan penelitian oleh Zhou et al., (2015) bahwa pada herba krokot ditemukan kandungan senyawa flavonoid. Menurut Devagaran \& Diantini (2012) salah satu senyawa yang memiliki kemampuan dapat meningkatkan sistem imun adalah senyawa flavonoid. Mekanisme flavonoid sebagai imunomodulator yaitu dengan meningkatkan aktivitas IL-12 dan proliferasi limfosit. Sel CD4+ akan mempengaruhi proliferasi limfosit kemudian menyebabkan sel Th-1 teraktivasi. Sel Th-1 yang teraktivasi akan mempengaruhi IFN- $\mathrm{Y}$ yang dapat mengaktifkan makrofag yang ditandai dengan meningkatnya aktivitas fagositosis secara cepat dan lebih efisien dalam membunuh antigen (Patroni \& Yuniarti, 2003).

\section{KESIMPULAN}

Berdasarkan hasil penelitian dan analisis data statistik, maka dapat disimpulkan bahwa :

1. Ekstrak etanol herba krokot (Portulaca oleracea L.) memiliki efek sebagai imunomodulator pada tikus putih (Rattus norvegicus) jantan. 
2. Ekstrak etanol herba krokot (Portulaca oleracea L.) dengan dosis $100 \mathrm{mg} / \mathrm{kgBB}, 200 \mathrm{mg} / \mathrm{kgBB}$, dan $400 \mathrm{mg} / \mathrm{kgBB}$ efektif berkhasiat sebagai imunomodulator pada tikus putih (Rattus norvegicus) jantan.

\section{DAFTAR PUSTAKA}

Andayani, D., Suprihartini, E., \& Astuti, M. (2018). Efek Antiinflamasi Ekstrak Etanol Krokot (Portulaca oleracea L.) pada Udema Tikus yang di Induksi Karagenin. Journal of Pharmaceutical Science and Clinical Research, 3(1), 43-49.

Antari, A. L. (2017). Imunologi Dasar. Yogyakarta: Deepublish.

Bellanti, A. J. (1989). Imunologi III. Yogyakarta: Gajah Mada University Press.

Devagaran, T. \& Diantini, A. (2012). Senyawa Imunomodulator Dari Tanaman. Bandung: Student eJournal.

Effendi, N. \& Widiastuti, H. (2014). Identifikasi Aktivitas Imunoglobulin M (IgM) Ekstrak Etanolik Daun Ceplukan (Physalis Minima Linn.) pada Mencit. Jurnal Kesehatan, 7(2), 353-360.

Emelda, A., Rahman, S., Hardianti. (2015). Efek Imunostimulan Infus Buah Mahkota Dewa (Phaleria Macrocarpa (Scheff.) Boerl.) Asal Kab. Sidrab Sulawesi Selatan Terhadap Sekresi Antibodi Tikus Putih (Rattus Norvegicus) Jantan Dengan Teknik Hemaglutinasi (Skripsi). Makassar: Fakultas Farmasi Universitas Muslim Indonesia.

Faradilla, M. (2013). Efek Imunomodulator Polisakarida Rimpang Temu Putih (Curcuma zedoaria (Chrtetm.) Roscoe). Jurnal Ilmu Kefarmasian Indonesia, 12, 273-278

Kusmardi, Shirly. K. \& Enif, E. T. (2007). Efek Imunomodulator Ekstrak Daun Ketepeng Cina (Cassia alata. L) Terhadap Aktivitas dan Kapasitas Fagositosis Makrofag. Makara Kesehatan, 11(2), 50-53.

Park, Y. M., Lee, H. Y., Kang, Y. G., Park, S. H., Lee, B. G., Park, Y. J., ... Lee, Y.-R. (2019). Immune-enhancing effects of Portulaca oleracea L.- based complex extract in cyclophosphamide-induced splenocytes and immunosuppressed rats. Food and Agricultural Immunology, 30(1), 13-24.

Patroni, R., \& Yuniarti, A. (2003). Pengaruh pemberian ekstrak etanol umbi bidara upas (Merremia mammosa) terhadap fagositosis makrofag dan produksi NO makrofag studi eksperimental Infeksi Salmonella Typhimurium pada mencit Balb/C. Semarang: Universitas Diponegoro.

Praworo, K. (2011). Terapi Medipic, Medical Picture. Jakarta: Penebar Plus.

Sri Harti, A. (2013). Imunologi Dasar \& Imunologi Klinis. Yogyakarta: Graha Ilmu.

Wati, A., Herman, H., Sari, D. P. (2013). Uji Hepatoterapi Ekstrak Etanol Buah Merah (Pandanus conoideus Lam.) Asal Kabupaten Jayawijaya Papua Dengan Parameter SGPT Terhadap Tikus Putih Jantan. Jurnal Bionature, 2(14), 100-104.

Zhou, Y., Xin, H., Rahman, K., Wang, S., Peng, C., Zhang, H. (2015). Poleracea L.: A Review of Phytochemistry and Pharmacological Effects. Biomed Res Int. 2015;2015:925631. 